\title{
Adsorption Characteristics of Albumin and Lysozyme on Heat-Treated Hydroxyapatite
}

\author{
Toshiyuki AKAZAWA, Masayoshi KOBAYASHI* and Kohei KODAIRA** \\ Hokkaido Industrial Research Institute, Nishi 11, Kita 19, Kita-ku, Sapporo-shi, Hokkaido 060 \\ *Department of Chemical System Engineering, Kitami Institute of Technology, 165, Koen-cho, Kitami-shi, Hokkaido 090 \\ **Division of Materials Science and Engineering, Graduate School of Engineering, Hokkaido University, \\ Nishi 8, Kita 13, Kita-ku, Sapporo-shi, Hokkaido 060
}

\author{
加熱処理した水酸アパタイトに対するアルブミンとリゾチームの吸着特性 \\ 赤澤敏之・小林正義* · 小平紘平** \\ 北海道立工業試験場, 060 北海道札幌市北区北19条西11丁目 \\ *北見工業大学化学システム工学科, 090 北海道北見市公園町 165 \\ **北海道大学大学院工学研究科物質工学専攻, 060 北海道札幌市北区北13条西 8 丁目
}

\begin{abstract}
Adsorption characteristics of bovine serum albumin (BSA) and lysozyme prepared from egg white (LSZ) were investigated on hydroxyapatite (HAp) powders which were prepared in a stream of water vapor and in air at the heating temperatures of 673-1473 K. The BSA or LSZ adsorption isotherm obtained on these HAp's in phosphate buffer solutions satisfied Langmuir's equation, regardless of the kind of gas atmosphere for the HAp heat treatment. The saturated amount of adsorption per surface area (designated by $A_{\mathrm{SA}}(\mathrm{B})$ for BSA and $A_{\mathrm{SA}}(\mathrm{L})$ for LSZ) and the heat of adsorption ( $Q_{\mathrm{B}}$ for BSA and $Q_{\mathrm{L}}$ for LSZ) increased and decreased, respectively, with gradual increase in the crystallite size of HAp at 673-1073 K (region I). At 1073-1473 K (region II), $A_{\mathrm{SA}}(\mathrm{B})$ and $A_{\mathrm{SA}}(\mathrm{L})$ appreciably increased, whereas $Q_{\mathrm{B}}$ and $Q_{\mathrm{L}}$ were gradually reduced due to the transforming morphology of HAp particles as well as grain growth. $A_{\mathrm{SA}}(\mathrm{L})$ became about fourfold larger than $A_{\mathrm{SA}}(\mathrm{B})$, and $Q_{\mathrm{L}}$ became 10-30\% higher than $Q_{\mathrm{B}}$ in the two regions, indicating that the adsorption ability of LSZ on the P-sites of HAp is stronger than that of BSA on the C-sites of HAp. The increase of HAp heating temperature can effectively enhance the growth of crystallite size and the transformation of microstructure, so that the total numbers of $C$ - and $P$-sites increase and both the basic strength of the $C$-sites and acid strength of the $P$-sites are reduced. The ratios of the numbers of the two sites $(P / C)$ were kept almost constant at $4.34 \pm 0.01$ in region $I$ and gradually increased from 4.34 to 4.75 in region II.
\end{abstract}

[Received June 12, 1996; Accepted September 19, 1996]

Key-words : Hydroxyapatite, Adsorption, Albumin, Lysozyme, Crystallite size, Microstructure, Heat of adsorption, Heat treatment

\section{Introduction}

Hydroxyapatite (HAp: $\left.\mathrm{Ca}_{10}\left(\mathrm{PO}_{4}\right)_{6}(\mathrm{OH})_{2}\right)$ with hexagonal crystal structure has been used as a material to make artificial bones and roofs of teeth because of excellent biocompatibility. HAp powder can also be applied as an adsorbent for biopolymers such as proteins and nucleic acids in packing materials for high-performance liquid chromatography since the proteins are easily adsorbed on HAp crystals because of high bioaffinity and desorbed without denaturation using phosphate eluents. ${ }^{1), 2)}$

As is well known, the surface active sites of hexagonal HAp for adsorption are classified into two groups:3) One is a positively charged site (C-site) which consists of two $\mathrm{Ca}^{2+}$ ions located on a rectangle $0.942 \mathrm{~nm}$ in length along the $a$ axis and $0.344 \mathrm{~nm}$ in length along the $c$-axis. The C-site is the position of the hydroxyl group on the $a$-face of HAp. The other is a negatively charged site ( $\mathrm{P}$-site) which is coordinated with six $\mathrm{O}^{2-}$ ions belonging to three $\mathrm{PO}_{4}{ }^{3-}$ ions and forming a hexagonal double-triangular array. The P-site is the position of the $\mathrm{Ca}^{2+}$ site on the $c$-face on HAp. The fine surface structure and surface distribution of the C- and Psites may possibly be influenced by the starting materials and preparation conditions of HAp which, as a result, should contribute to the selective adsorption of proteins on each of the sites.

Acidic proteins with isoelectric points $\left(E_{0}\right)<\mathrm{pH} 7.0$ and basic proteins with $E_{0}>\mathrm{pH} 7.0$ are selectively adsorbed on the $\mathrm{C}$-sites and $\mathrm{P}$-sites, respectively.3) Accordingly, bovine serum albumin (BSA) having $E_{0}=\mathrm{pH} 4.2-4.8$, which is an acidic one-chain protein, ${ }^{4)}$ and lysozyme from egg white (LSZ) having $E_{0}=\mathrm{pH} \mathrm{10.0-11.0,} \mathrm{which} \mathrm{is} \mathrm{a} \mathrm{basic} \mathrm{one-chain}$ protein, ${ }^{5)}$ are adsorbed on the $\mathrm{C}$ - and $\mathrm{P}$-sites, respectively. ${ }^{3}$ ) Grant and Dehl, $\left.{ }^{6}\right)$ Arai and Norde, ${ }^{7}$ ) Bowen and Hughes ${ }^{8)}$ and Kandori et al. ${ }^{9}$ demonstrated that the adsorption of BSA or LSZ on medical polymer materials such as polyethylene, polystyrene and $\mathrm{SiO}_{2}$ films satisfied Langmuir's equation. The saturated amounts were evaluated to be $1-5 \mathrm{mg}$. $\mathrm{m}^{-2}$ and the form of adsorbed molecule was interpreted to be a side-on form of BSA or LSZ.

In our previous papers, ${ }^{10), 11)}$ quantitative relationships between the adsorption behavior of BSA and the crystal surface characteristics of two HAp powders, which were prepared by wet syntheses using cattle bones ( $r-H A p)$ or reagents (s-HAp) and heated at 673-1073 K, were investigated in detail. The saturated amount and heat of BSA adsorption linearly increased and decreased, respectively, with increasing crystallite size of HAp. The straight lines obtained gave different slopes for the r-HAp and s-HAp samples.

The increase in the crystallite size due to heat treatment of the HAp powders might affect the occurrence of the Cand $\mathrm{P}$-sites on the crystal surface, which is responsible for the variation in the acid or basic strength of adsorption sites, together with a change in the morphology of HAp crystallite particles. The surface proportions of the $\mathrm{C}$ - and P-sites on the HAp's can be evaluated from the ratios of the saturated amounts of BSA and LSZ. The chemical nature of the two sites may effectively be compared in terms of the heats of adsorption for BSA and LSZ as a function of the 
heating temperatures of the HAp's.

The aims of this study are to elucidate the effects of heating the HAp powders in a wide temperature range of 673$1473 \mathrm{~K}$ on the surface properties such as the crystallite size and microstructure, and to evaluate the chemical nature of the HAp surfaces by comparing the adsorption behaviors of BSA and LSZ.

\section{Experimental}

A synthetic HAp was prepared using guaranteed grade $\mathrm{Ca}\left(\mathrm{NO}_{3}\right)_{2} \cdot 4 \mathrm{H}_{2} \mathrm{O}$ and $\left(\mathrm{NH}_{4}\right)_{2} \mathrm{HPO}_{4}$ reagents as starting materials by the wet method. ${ }^{11), 12)}$ The stoichiometric HAp powder with the composition ratio of $(\mathrm{Ca} / \mathrm{P})=1.67$ was obtained by the preparation at $333 \mathrm{~K}$ and $\mathrm{pH}$ 10.0-10.5 for $24 \mathrm{~h}$. The HAp powders prepared were heated using a cyclic electric furnace at $673-1473 \mathrm{~K}$ for $24 \mathrm{~h}$ in air (designated as $\mathrm{s}-\mathrm{HAp}(\mathrm{Air}))$ or in a stream of water vapor controlled with nitrogen gas flow (designated as $\mathrm{s}-\mathrm{HAp}\left(\mathrm{H}_{2} \mathrm{O}\right)$ ). The heat treatment temperatures were controlled within a temperature fluctuation of $1 \mathrm{~K}$ to obtain $\mathrm{s}-\mathrm{HAp}$ with reproducible surface characteristics. These samples gave a single phase of HAp and were well crystallized by the heat treatment at $1073-1473 \mathrm{~K}$, regardless of the kind of gas atmosphere.

The crystalline phases of the powders obtained were identified by X-ray powder diffraction (XRD) using $\mathrm{Cu} \mathrm{K} \alpha_{1}$ radiation. The lattice parameters of the HAp phase were determined by the same method as in the previous studies.12),13) The crystallite sizes were calculated by both Warren and Aberwach's analytical method ${ }^{11)}$ and Scherrer's equation using the (002) or (200) plane of HAp. ${ }^{14)}$ Field emissionscanning electron microscopy (FE-SEM) images of the samples were taken to observe the morphology and microstructure of crystallites. The composition ratio of $\mathrm{Ca}^{2+}$ to $\mathrm{PO}_{4}{ }^{3-}$ ions $(\mathrm{Ca} / \mathrm{P})$ was determined by electron probe microanalysis (EPMA) and chemical analysis by means of chelate titration and molybdenum acid colorimetry. 11) The BET specific surface area $\left(S_{\mathrm{A}}\right)$ and the pore size distribution $\left(1 \mathrm{~nm}<\right.$ pore size $\left.\left(r_{\mathrm{P}}\right)<15 \mathrm{~nm}\right)$ were measured by $\mathrm{N}_{2}$ adsorption at $77 \mathrm{~K}$ in the equilibrium pressure range of $0-$ $0.097 \mathrm{MPa} .11)$

BSA and LSZ were chosen as the typical acidic and basic proteins to evaluate adsorption behavior on HAp powders. HAp powders $(0.1 \mathrm{~g})$ were added into solutions $\left(10 \mathrm{~cm}^{3}\right)$ containing $0.3-3.0 \mathrm{mg} \cdot \mathrm{cm}^{-3}$ of BSA or LSZ, which were adjusted using a mixed solution of $20 \mathrm{mmol} \cdot \mathrm{dm}^{-3}$ phosphate buffers $\left(\mathrm{KH}_{2} \mathrm{PO}_{4}\right.$ and $\left.\mathrm{K}_{2} \mathrm{HPO}_{4}\right)$ to maintain the $\mathrm{pH}$ at 6.97.1. The mixtures were agitated with magnetic stirrer at $282 \mathrm{~K}$ and $295 \mathrm{~K}$ for $80-100 \mathrm{~h}$. After centrifuging them, the absorbance at $280 \mathrm{~nm}$ for BSA or LSZ $\left.{ }^{10)}, 11\right)$ of the solutions was measured by ultraviolet spectroscopy (Shimadzu UV 3100-PC). From the absorbance obtained, the equilibrium concentration and the amounts of BSA or LSZ adsorption were calculated. The isosteric differential heat of adsorption for each protein was determined from the two adsorption isotherms at $282 \mathrm{~K}$ and $295 \mathrm{~K}$ using the ClausiusClapeyron equation. ${ }^{15}$

\section{Results and discussion}

3.1 Apparent surface characteristics of HAp crystals by heat treatment

Figure 1 shows the typical XRD patterns of the HAp powders which were heated at $1073-1473 \mathrm{~K}$ for $24 \mathrm{~h}$ in a stream of water vapor. The lattice parameters $(a=0.942 \mathrm{~nm}$ and $c=0.688 \mathrm{~nm}$ ) of the samples were in good agreement with those of the JCPDS (9-432) card.

Evaluating the surface characteristics, the crystallite sizes of the s-HAp $\left(\mathrm{H}_{2} \mathrm{O}\right)$ powders were calculated by two different methods, Scherrer's equation (designated as $C_{\mathrm{S}, \mathrm{S}}$ ) and Warren and Aberwach's analytical method (designated as $\left.C_{\mathrm{S}, \mathrm{WA}}\right)$, and the results are shown in Fig. 2. $C_{\mathrm{S} \text {,WA }}$ gradually increased from about 16 to $42 \mathrm{~nm}$ at $673-1073 \mathrm{~K}$ (region I) and became almost constant at $42 \mathrm{~nm}$ in the range of 1073-1473 K (region II) although the crystallinity of HAp became slightly better with increasing heating temperature. Considering the anisotropy of crystal growth, $C_{\mathrm{S}, \mathrm{S}}$ evaluated using the (200) plane of HAp exhibited the same tendency as did $C_{\mathrm{S}, \mathrm{WA}}$, whereas $C_{\mathrm{S}, \mathrm{S}}$, using the (002) plane of HAp, was in the range of $35-40 \mathrm{~nm}$ in all temperature regions. From these results, one may infer that the crystallite growth in region I is mainly caused by the growth of

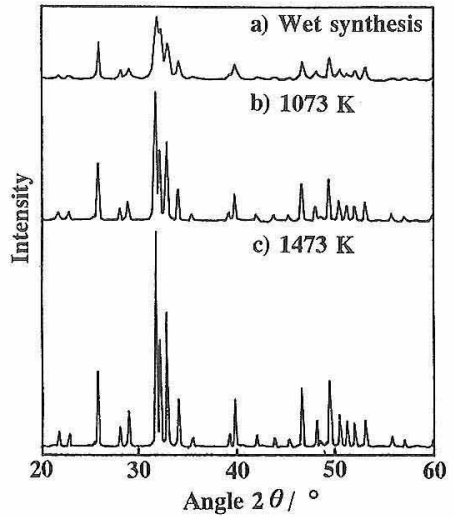

Fig. 1. XRD patterns of the $\mathrm{s}-\mathrm{HAp}$ powders heated for $24 \mathrm{~h}$ in a stream of water vapor.

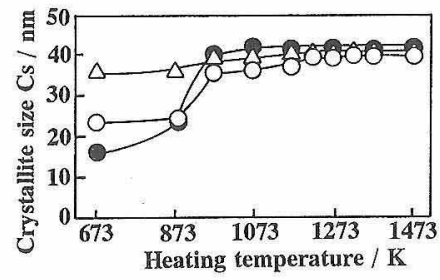

Fig. 2. Crystallite sizes calculated using Scherrer's equation $\left(C_{\mathrm{S}, \mathrm{S}}\right)$ and Warren and Aberwach's analytical method $\left(C_{\mathrm{S}, \mathrm{WA}}\right)$ for the $\mathrm{s}-\mathrm{HAp}$ powders heated for $24 \mathrm{~h}$ in a stream of water vapor. $O C_{\mathrm{S}, \mathrm{S}}$ of $(200)$ plane, $\triangle C_{\mathrm{S}, \mathrm{S}}$ of $(002)$ plane, $C_{\mathrm{S}, \mathrm{WA}}$.

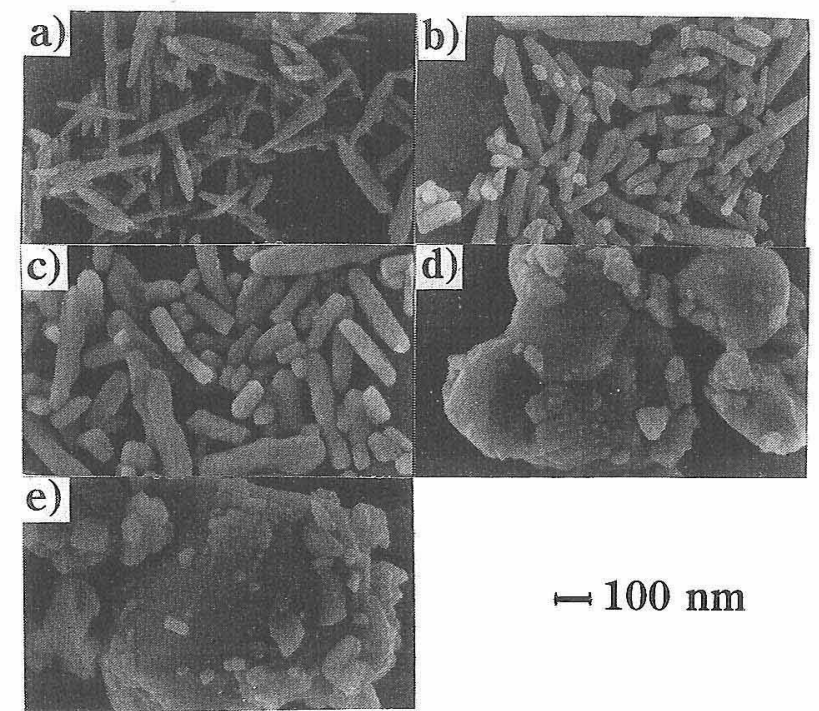

Fig. 3. FE-SEM photographs of the s-HAp powders heated for $24 \mathrm{~h}$ in a stream of water vapor. (a) $673 \mathrm{~K}$, (b) $873 \mathrm{~K}$, (c) $1073 \mathrm{~K}$, (d) $1273 \mathrm{~K}$ and (e) $1473 \mathrm{~K}$. 
the $a$-face in HAp. Figure 3 shows the FE-SEM photographs of the crystallite morphology of s-HAp $\left(\mathrm{H}_{2} \mathrm{O}\right)$. One can clearly recognize needle-like particles with aspect ratios of $5-10$ at $673 \mathrm{~K}$, prismatic ones with $3-5$ at $873-1073 \mathrm{~K}$ and platelike ones at $1273-1473 \mathrm{~K}$. This transformation of the crystallite morphology should affect the adsorption behavior of proteins on their surfaces. For the s-HAp (Air) powders, the variation in the crystallite size and the transformation of microstructure were similarly recognized as those of $\mathrm{s}-\mathrm{HAp}\left(\mathrm{H}_{2} \mathrm{O}\right)$.

Figure 4 shows the specific surface areas $\left(S_{\mathrm{A}}\right)$ of the sHAp powders as a function of the heating temperature. $S_{\mathrm{A}}$ decreased dramatically from $59 \mathrm{~m}^{2} \cdot \mathrm{g}^{-1}$ at $673 \mathrm{~K}$ to about 2 $\mathrm{m}^{2} \cdot \mathrm{g}^{-1}$ at $1473 \mathrm{~K}$. This decrease corresponds to the observed changes in surface textures accompanying grain growth (see Fig. 3). s-HAp $\left(\mathrm{H}_{2} \mathrm{O}\right)$ had a slightly larger $\mathrm{S}_{\mathrm{A}}$ than did s-HAp (Air) at 1073-1473 K (region II), suggesting that water vapor inhibits the sintering of HAp particles at high temperatures, as discussed in the previous papers. ${ }^{10), 11)}$

3.2 Classification of HAp pore structures on the basis of the molecular size difference between BSA and LSZ as adsorbents

To evaluate the adsorption behavior of proteins on the HAp crystals, it is necessary to investigate the quantitative relationship between the molecular sizes of proteins and the pore structure of HAp. As is well known, the BSA and LSZ molecules have ellipsoidal structures of $4 \times 4 \times 14 \mathrm{~nm}$ and $3 \times 3 \times 4.5 \mathrm{~nm}$ in the normal conformation, respectively.4),5) Based on the molecular sizes of the two proteins, the pore size distribution of $\mathrm{s}-\mathrm{HAp}$ can be classified into five sizes of $7 \mathrm{~nm}<r_{\mathrm{P}}<15 \mathrm{~nm}$ (designated as corresponding specific surface area $\left.S_{\mathrm{A} 1}\right), 2 \mathrm{~nm}<r_{\mathrm{P}}<15 \mathrm{~nm}\left(S_{\mathrm{A} 2}\right), 1 \mathrm{~nm}<r_{\mathrm{P}}<15 \mathrm{~nm}$ $\left(S_{\mathrm{A} 3}\right), 2.25 \mathrm{~nm}<r_{\mathrm{p}}<15 \mathrm{~nm}\left(S_{\mathrm{A} 4}\right)$ and $1.5 \mathrm{~nm}<r_{\mathrm{P}}<15 \mathrm{~nm}$ $\left(S_{\mathrm{A} 5}\right) . S_{\mathrm{A} 1}$ or $S_{\mathrm{A} 4}$ is large enough in pore size for the diffusion of BSA or LSZ molecules and therefore the proteins can pass through the pores in any orientation, i.e., end-on or side-on. The values of $\left(S_{\mathrm{A} 2}-S_{\mathrm{A} 1}\right)$ and $\left(S_{\mathrm{A} 5}-S_{\mathrm{A} 4}\right)$ respectively mean the pore surface areas with $r_{\mathrm{P}}=2-7 \mathrm{~nm}$ for BSA and 1.5-2.25 nm for LSZ, which accommodate only end-on diffusion. For the s-HAp powders heated at 1273$1473 \mathrm{~K}$, the calculation of surface areas was impossible because the total pore volumes of the samples were too small. Figure 5 shows the surface proportions of $S_{\mathrm{A} 1} / S_{\mathrm{A} 3},\left(S_{\mathrm{A} 2}-\right.$ $\left.S_{\mathrm{A} 1}\right) / S_{\mathrm{A} 3}, S_{\mathrm{A} 4} / S_{\mathrm{A} 3}$ and $\left(S_{\mathrm{A} 5}-S_{\mathrm{A} 4}\right) / S_{\mathrm{A} 3}$ for the s-HAp powders for comparison between the heating temperatures of $673 \mathrm{~K}$ and $1073 \mathrm{~K}$. The $S_{\mathrm{A} 1} / S_{\mathrm{A} 3}$ ratio is reduced $20-30 \%$ due to the acceleration of sintering in temperature region $I$ $(673-1073 \mathrm{~K})$. On the other hand, $\left(S_{\mathrm{A} 2}-S_{\mathrm{A} 1}\right) / S_{\mathrm{A} 3}, S_{\mathrm{A} 4} / S_{\mathrm{A} 3}$ and $\left(S_{\mathrm{A} 5}-S_{\mathrm{A} 4}\right) / S_{\mathrm{A} 3}$ show no appreciable change. Such evidence indicates that the variation in the amount of LSZ adsorption is not related to the pore size proportions of s-HAp

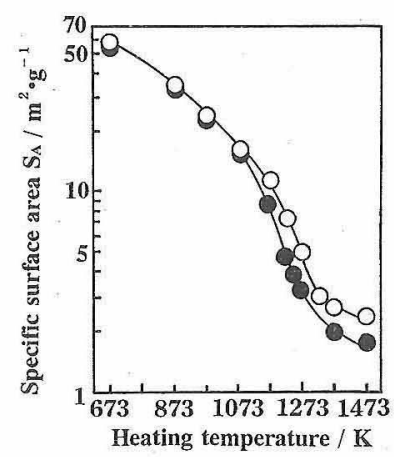

Fig. 4. Influence of heat treatment on the BET specific surface areas of the HAp powders. $\bigcirc$ s-HAp $\left(\mathrm{H}_{2} \mathrm{O}\right), \bigcirc \mathrm{s}-\mathrm{HAp}$ (Air).

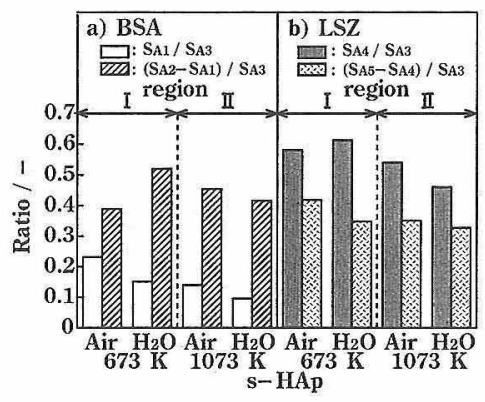

Fig. 5. Ratios of the specific surface areas calculated from various pore sizes for the s-HAp powders in comparison with the BSA or LSZ molecular size. $S_{\mathrm{A} 1}$ : values for $7 \mathrm{~nm}<r_{\mathrm{P}}<15 \mathrm{~nm} ; S_{\mathrm{A} 2}: 2$ $\mathrm{nm}<\gamma_{\mathrm{P}}<15 \mathrm{~nm} ; \quad S_{\mathrm{A} 3}: 1 \mathrm{~nm}<\gamma_{\mathrm{P}}<15 \mathrm{~nm} ; \quad S_{\mathrm{A} 4}: 2.25 \mathrm{~nm}<\gamma_{\mathrm{P}}<15$ $\mathrm{nm} ; S_{\mathrm{A} 5}: 1.5 \mathrm{~nm}<r_{\mathrm{P}}<15 \mathrm{~nm}$.

which accommodate the diffusion of LSZ.

3.3 Surface active site distribution elucidated from BSA and LSZ adsorptions

Figure 6 shows typical examples of the adsorption isotherms for BSA on s-HAp $\left(\mathrm{H}_{2} \mathrm{O}\right)$. The amount of adsorption $\left(A_{\mathrm{W}}\right)$ relative to the weight of HAp increased monotonically with increasing equilibrium concentration $\left(C_{\mathrm{E}}\right)$ of BSA. Similar adsorption isotherms of BSA or LSZ were obtained for all the samples. The good linear correlations obtained in the ( $C_{\mathrm{E}} / A_{\mathrm{W}}$ versus $\left.C_{\mathrm{E}}\right)$ plots clearly indicated that the adsorptions of the two proteins adsorption can obey the Langmuir equation in all $\mathrm{s}-\mathrm{HAp}$ powders. Using this equation, the saturated amounts of adsorption $\left(A_{\mathrm{SW}}(\mathrm{B})\right)$ for $\mathrm{BSA}$ and $\left(A_{\mathrm{SW}}(\mathrm{L})\right)$ for LSZ relative to the weight of HAp can be calculated, and typical examples of the results obtained are shown in Fig. 7 as a function of the heating temperatures. $A_{\mathrm{SW}}(\mathrm{B})$ and $A_{\mathrm{SW}}(\mathrm{L})$ decreased with rising heat treatment temperature because of the reduction in the specific surface area.

To investigate the characteristics of the active sites on HAp crystal surfaces, the saturated amounts of adsorption

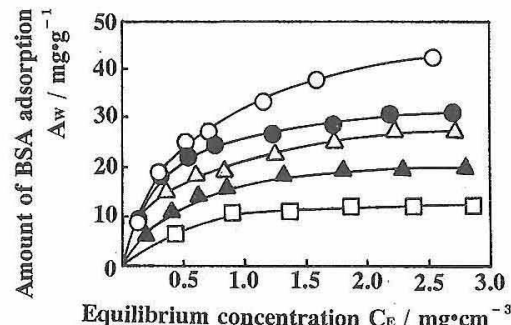

Fig. 6. Adsorption isotherms of $\mathrm{BSA}$ at $295 \mathrm{~K}$ and $\mathrm{pH} 6.9-7.1$ in $20 \mathrm{mmol} \cdot \mathrm{dm}^{-3} \mathrm{KH}_{2} \mathrm{PO}_{4}$ and $\mathrm{K}_{2} \mathrm{HPO}_{4}$ solutions for the s-HAp heated in a stream of water vapor. $\bigcirc 673 \mathrm{~K}, \bigcirc 873 \mathrm{~K}, \triangle 1073 \mathrm{~K}$, $\triangle 1273 \mathrm{~K}, \square 1473 \mathrm{~K}$.

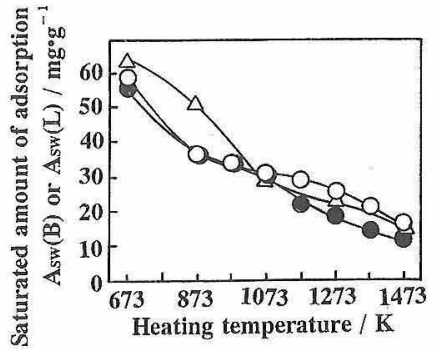

Fig. 7. Saturated amounts of adsorption for the two proteins as a function of the heating temperature of HAp powders. $O B S A$ on $s-$ $\mathrm{HAp}\left(\mathrm{H}_{2} \mathrm{O}\right), \triangle \mathrm{BSA}$ on s-HAp (Air), $\triangle \mathrm{LSZ}$ on s-HAp $\left(\mathrm{H}_{2} \mathrm{O}\right)$. 


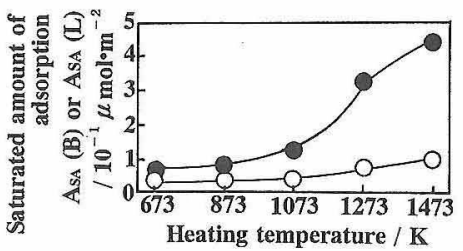

Fig. 8. Effects of heat treatment of $\mathrm{s}-\mathrm{HAp}\left(\mathrm{H}_{2} \mathrm{O}\right)$ on the saturated amounts of adsorption for the two proteins relative to the surface area of HAp. O BSA, O LSZ.

per surface area of $\mathrm{HAp}$ (designated as $A_{\mathrm{SA}}(\mathrm{B})$ for $\mathrm{BSA}$ and $A_{\mathrm{SA}}(\mathrm{L})$ for $\mathrm{LSZ}$ ) were calculated from the specific surface areas in Fig. 4 and the results are shown in Fig. 8. $A_{\mathrm{SA}}$ (L) was 2-4 times larger than $A_{\mathrm{SA}}(\mathrm{B})$, depending on the temperature range. In particular, $A_{\mathrm{SA}}(\mathrm{L})$ increased dramatically from $0.73 \mu \mathrm{mol} \cdot \mathrm{m}^{-2}$ to $4.39 \mu \mathrm{mol} \cdot \mathrm{m}^{-2}$, whereas $A_{\mathrm{SA}}$ (B) was $0.17-0.94 \mu \mathrm{mol} \cdot \mathrm{m}^{-2}$. The calculated ratio of $A_{\mathrm{SA}}$ (L) to $A_{\mathrm{SA}}(\mathrm{B})$ was almost constant at $4.34 \pm 0.01$ in region I $(673-1073 \mathrm{~K})$. The $A_{\mathrm{SA}}(\mathrm{L}) / A_{\mathrm{SA}}(\mathrm{B})>4.3$ obtained in all temperature ranges cannot be explained by the molecular size difference between BSA and LSZ, since the molecular size ratios of LSZ $(3 \times 3 \times 4.5 \mathrm{~nm})$ to BSA $(4 \times 4 \times 14 \mathrm{~nm})$ are less than 3.0, which is the estimated value on the assumption that the molecules of proteins are adsorbed in only side-on or end-on form. In region II (1073-1473 K), the $A_{\mathrm{SA}}(\mathrm{L}) / A_{\mathrm{SA}}(\mathrm{B})$ values increased from 4.34 to 4.75 . This increase indicates a change in the surface distributions of the P-sites for LSZ adsorption and the C-sites for BSA adsorption, which may be a result of a rearrangement of the crystal surface structure, even though the apparent crystallite size was constant in region II (see Fig. 2). As shown in Fig. 3, the morphology transformed significantly from prismatic particles with aspect ratios of $3-5$ at $873-1073 \mathrm{~K}$ to platelike ones at $1273-1473 \mathrm{~K}$. The transformation is induced by the growth of the $c$-face in HAp. Thus, the increase of $A_{\mathrm{SA}}(\mathrm{L}) / A_{\mathrm{SA}}(\mathrm{B})$ might be related to the growth of platelike particles.

3.4 Characterization of adsorption forms of BSA and LSZ

For further consideration of the adsorption behavior of BSA and LSZ, the fine structure of adsorbed molecules on each active site was evaluated. The total number $\left(A_{\mathrm{N}}\right)$ of each type of protein molecule adsorbed on HAp can be calculated using

$$
A_{\mathrm{N}}=A_{\mathrm{SA}} \cdot S_{\mathrm{A}} \cdot N_{0} \cdot M W^{-1}
$$

$N_{0}$ is Avogadro's number and $M W$ is molecular weight (66000 for BSA and 14300 for LSZ) ${ }^{4), 5)}$ Assuming an HAp surface which is homogeneously covered with a monolayer of protein molecules, the apparent total surface area $\left(S_{\mathrm{T}}\right)$ calculated from the adsorption is expressed as a product of the efficient surface area (designated as $S_{\mathrm{B}}$ for BSA and $S_{\mathrm{L}}$ for LSZ) occupied by one molecule and $A_{\mathrm{N}}$.

$$
S_{\mathrm{T}}=A_{\mathrm{N}} \cdot S_{\mathrm{B}}\left(\text { or } S_{\mathrm{L}}\right)
$$

Provided that all the BSA or LSZ molecules are adsorbed on the HAp surface by close packing structure in either the side-on or end-on form, and that an adsorbed molecule occupies one hexagonal surface area on $\mathrm{HAp}, \mathrm{S}_{\mathrm{B}, \mathrm{S}}$ or $\mathrm{S}_{\mathrm{L}, \mathrm{S}}$ (sideon) and $S_{\mathrm{B}, \mathrm{E}}$ or $S_{\mathrm{L}, \mathrm{E}}$ (end-on) can be calculated from geometrical interpretation ${ }^{15)}$ using $M W, N_{0}$ and particle density $\left(d_{\mathrm{A}, \mathrm{B}}=1.364 \times 10^{3} \mathrm{~kg} \cdot \mathrm{m}^{-3}\right.$ for BSA and $d_{\mathrm{A}, \mathrm{L}}=1.399 \times 10^{3}$ $\mathrm{kg} \cdot \mathrm{m}^{-3}$ for $\left.\mathrm{LSZ}\right)^{4), 5)}$ in the following manner.

$$
\begin{aligned}
S_{\mathrm{L}, \mathrm{S}} & =2 \cdot 3^{1 / 2} \cdot M W^{2 / 3} \cdot\left(4 \cdot 2^{1 / 2} \cdot N_{0} \cdot d_{\mathrm{A}, \mathrm{L}}\right)^{-2 / 3} \\
& =0.72 \times 10^{-17} \mathrm{~m}^{2} \\
S_{\mathrm{L}, \mathrm{E}} & =2 \cdot 3^{1 / 2}\left(1.5 \times 10^{-9}\right)^{2}=0.78 \times 10^{-17} \mathrm{~m}^{2} \\
S_{\mathrm{B}, \mathrm{S}} & =\left(2.04 \times 10^{-17} \mathrm{~m}^{2}\right)^{11)} \\
S_{\mathrm{B}, \mathrm{E}} & =\left(1.39 \times 10^{-17} \mathrm{~m}^{2}\right)^{11)}
\end{aligned}
$$

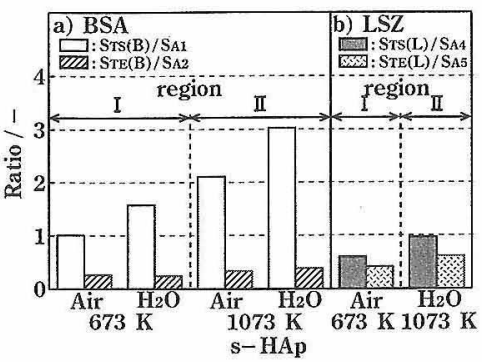

Fig. 9. Ratios of the total efficient surface areas of BSA or LSZ to the total surface areas calculated from various pore sizes of the sHAp powders. $S_{\mathrm{TS}}$ (B) $/ S_{\mathrm{A} 1}$ : BSA adsorbed in only side-on form, $S_{\mathrm{TE}}(\mathrm{B}) / S_{\mathrm{A} 2}$ : BSA adsorbed in only end-on form, $S_{\mathrm{TS}}(\mathrm{L}) / S_{\mathrm{A} 4}$ : LSZ adsorbed in only side-on form, $S_{\mathrm{TE}}(\mathrm{L}) / S_{\mathrm{A} 5}$ : LSZ adsorbed in only end-on form.

BSA adsorption, the efficient surface area occupied by one molecule is about 1.5 times larger than that for end-on adsorption, but LSZ shows no appreciable change regardless of the adsorption orientation of the molecule. Accordingly, different apparent total surface areas calculated from the amount of protein adsorption ( $S_{\text {TS }}$ in the case of only sideon forms or $S_{\text {TE }}$ in the case of only end-on forms) can be obtained by substituting Eqs. (1), (3)-(6) for Eq. (2), depending on the adsorption forms.

Figure 9 shows the ratios of the total efficient surface areas evaluated from the molecular sizes of the proteins to the total surface areas calculated from the pore size distribution of the s-HAp. The ratios of $S_{\mathrm{T}}$ to the specific surface areas calculated from the pore volumes (designated as $R_{\mathrm{S}, \mathrm{B}}$ $=S_{\mathrm{TS}} / S_{\mathrm{A} 1}$ or $R_{\mathrm{E}, \mathrm{B}}=S_{\mathrm{TE}} / S_{\mathrm{A} 2}$ for $\mathrm{BSA}$ and $R_{\mathrm{S}, \mathrm{L}}=S_{\mathrm{TS}} / S_{\mathrm{A} 4}$ or $R_{\mathrm{E}, \mathrm{L}}=S_{\mathrm{TE}} / S_{\mathrm{A} 5}$ for $\mathrm{LSZ}$ ) will indicate the adsorption form. $R_{\mathrm{S}, \mathrm{B}}$ and $R_{\mathrm{E}, \mathrm{B}}$ of s-HAp heated at $1073 \mathrm{~K}$ become $192-209 \%$ and $30-61 \%$ higher than those of s-HAp heated at $673 \mathrm{~K}$. Moreover, $R_{\mathrm{S}, \mathrm{B}}$ for the side-on form becomes much larger than one, but $R_{\mathrm{E}, \mathrm{B}}$ for the end-on form becomes less than one throughout the entire temperature range. These phenomena are strong evidence that the BSA adsorption orientation transforms from a mixture of side-on and end-on forms at $673 \mathrm{~K}$ to an end-on rich form at $1073 \mathrm{~K}$. On the other hand, $R_{\mathrm{S}, \mathrm{L}}$ and $R_{\mathrm{E}, \mathrm{L}}$ of s-HAp $(1073 \mathrm{~K}$ ) become $61 \%$ and $48 \%$ higher than those of s-HAp $(673 \mathrm{~K})$. However, both $R_{\mathrm{S}, \mathrm{L}}$ and $R_{\mathrm{E}, \mathrm{L}}$ are less than one in the range of $673-$ $1073 \mathrm{~K}$ (region I). The LSZ molecules on HAp can be adsorbed in any adsorption forms.

Accordingly, the adsorption of LSZ on HAp will not be influenced as much as that of BSA by the heat treatment of s-HAp powder in region $I$, because LSZ has a smaller anisotropy of molecular size compared to the pore sizes.

3.5 Active site characterization evaluated from the heat of adsorption for BSA and LSZ

The isosteric differential heat of adsorption $\left(Q_{\mathrm{B}}\right)$ for BSA and $\left(Q_{L}\right)$ for LSZ can be calculated using the ClausiusClapeyron equation. Figure 10 shows $Q_{\mathrm{B}}$ and $Q_{\mathrm{L}}$ as a func-

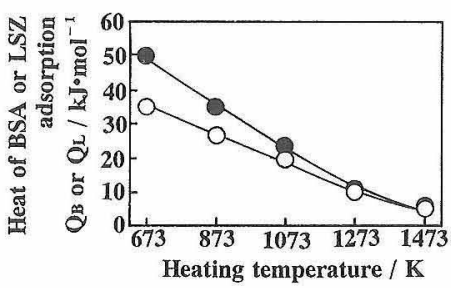

Fig. 10. Relationships between the heats of adsorption for the two proteins and the heating temperature of $\mathrm{s}-\mathrm{HAp}\left(\mathrm{H}_{2} \mathrm{O}\right)$. O $\mathrm{BSA}$, LSZ. 
tion of the heating temperature of s-HAp $\left(\mathrm{H}_{2} \mathrm{O}\right) . Q_{\mathrm{L}}$ became $10-30 \%$ higher than $Q_{\mathrm{B}}$ at $673-1073 \mathrm{~K}$ (region I ). According to the experimental results reported by Okuyama et al. ${ }^{16)}$ and Honda et al., ${ }^{17)}$ provided that BSA and LSZ proteins are separated using a column packed with HAp powder in phosphate buffer solutions by the linear gradient method, LSZ always has longer elution time than BSA in the liquid chromatograms. In addition, the separation peak of LSZ is much sharper and higher than that of BSA. These findings support that in the crystal surface of s-HAp powders heated in region $I$, the acid strength of the P-sites for adsorbing LSZ molecules is stronger than the basic strength of the C-sites for adsorbing BSA molecules.

As seen in Fig. 10, $Q_{\mathrm{B}}$ and $Q_{\mathrm{L}}$ values gradually decreased with rising heating temperatures of HAp. For BSA molecules, as one possible explanation, the adsorption orientation may gradually transform from a mixture of the side-on and end-on forms to the end-on rich form with crystallite growth. However, for LSZ molecules, the reduction of $Q_{\mathrm{L}}$ in region I cannot be interpreted by the same change in adsorption form because LSZ has smaller molecular size and anisotropy than BSA. As a possible explanation for the reduction in $Q_{\mathrm{L}}$ and $Q_{\mathrm{B}}$, it is proposed that the activity of each of the sites having the acid or basic strength, which is indicated as adsorption ability, is reduced on HAp surfaces in region I because of crystallite growth. At present, details on the cause of the $Q_{\mathrm{L}}$ reduction are still unclear. Moreover, in region II (1073-1473 K), the significant transformation of morphology may accelerate the reduction of the acid or basic strength, as well as enhance the variations in the total numbers and surface proportions of the Cand P-sites. Accordingly, the changes in the crystallite size and morphology of HAp due to heating are important factors which control the selectivity of BSA and LSZ adsorptions.

Bowen and Hughes ${ }^{8)}$ demonstrated that the adsorption enthalpies of BSA in $0.01 \mathrm{~mol} \cdot \mathrm{dm}^{-3}$ tris buffer solutions were $0.2-56.0 \mathrm{~kJ} \cdot \mathrm{mol}^{-1}$ for cellulose QA52 and $0.5-24.6$ $\mathrm{kJ} \cdot \mathrm{mol}^{-1}$ for polyethyleneimine PL-SAX1000. Also, Arai and Norde ${ }^{18)}$ found that the adsorption enthalpies of LSZ in $0.05 \mathrm{~mol} \cdot \mathrm{dm}^{-3}$ phosphate buffer at $\mathrm{pH} 7.0$ were $50-200$ $\mathrm{kJ} \cdot \mathrm{mol}^{-1}$ on polyoxymethylene single crystals. All $Q_{\mathrm{B}}$ and $Q_{\mathrm{L}}$ values obtained in our study fell within the values reported in those papers.

Taking into account these reproducible results, it is concluded that the adsorption behaviors of BSA and LSZ on sHAp powders are strongly influenced by the basic or acid strength of the $\mathrm{C}$ - or $\mathrm{P}$-site and the proportion of occurrences of the active sites, which are governed by the crystallite size and morphology of HAp depending on the heating temperature and gas atmosphere.

\section{Conclusions}

The physicochemical nature of the surface of stoichiometric HAp powders was substantially changed according to the heating conditions, and the variations in surface characteristics were elucidated from analysis of the adsorption behaviors of BSA and LSZ. The results obtained are summarized as follows.

(1) The microstructures of HAp transformed from needlelike particles with aspect ratios of $5-10$ at $673 \mathrm{~K}$ to prismatic ones with aspect ratios of 3-5 at 873-1073 K and platelike ones at $1273-1473 \mathrm{~K}$, regardless of the kind of gas atmosphere.

(2) The adsorption of BSA or LSZ on these HAp's in phosphate buffer solutions obeyed the Langmuir isotherm equation. The saturated amount of adsorption relative to the surface area of HAp and heat of adsorption for the two proteins respectively, increased and decreased with rising heat treatment temperature.

(3) The adsorption orientation of LSZ was not influenced as much as that of BSA by the heat treatment of HAp, because LSZ has smaller molecular size and anisotropy.

(4) The physicochemical consideration of the active sites on the HAp surfaces evaluated from the adsorption behaviors of BSA and LSZ indicated that (1) the increase in the total numbers of the $\mathrm{C}$ - and P-sites and (2) the weakening of the acid or basic strength may be due to crystallite growth and morphology transformation of HAp powders depending on the heating temperatures.

Acknowledgments The authors thank Mr. T. Kanazawa of the Application and Research Center, JEOL Ltd., Co., for his assistance in the observation of the microstructures using the field emission-scanning electron microscope.

\section{References}

1) T. Kawasaki, K. Ikeda, S. Takahashi and Y. Kuboki, Eur. J. Biochem., 155, 249-57 (1986).

2) T. Kawasaki, W. Kobayashi, K. Ikeda, S. Takahashi and H. Monma, Eur. J. Biochem., 157, 291-95 (1986).

3) T. Kawasaki, M. Niikura and Y. Kobayashi, J. Chromatogr., 515, 91-123 (1990)

4) K. Aoki, T. Takagi and H. Terada, "Kesseiarubumin Seitainiokeru sono Yakuwari”, Kodansha (1984) p. 1, p. 13.

5) K. Imabori and H. Yamakawa, "Seikagakujiten", Tokyo Kagakudojin (1989) p. 1333, p. 1334.

6) W. H. Grant and R. E. Dehl, "Adhesion and Adsorption of Polymers", Plenum Press (1979) p. 827.

7) T. Arai and W. Norde, Colloids and Surfaces, 51, 17-28 (1990).

8) W. Bowen and D. T. Hughes, J. Colloid Interface Sci., 158 , 395-402 (1993).

9) T. Kandori, S. Sawai, Y. Yamamoto, H. Saito and T. Ishikawa, Colloids and Surfaces, 68, 283-89 (1992).

10) T. Akazawa and M. Kobayashi, Abstract of the 11th Symposium on Japanese Association of Inorganic Phosphorus Chemistry (1996) pp. 33-34.

11) T. Akazawa and M. Kobayashi, J. Ceram. Soc. Japan, 104, 284-90 (1996)

12) T. Akazawa and K. Kodaira, Phosphorus Res. Bull., 1, 215-20 (1991).

13) T. Akazawa and K. Kodaira, Phosphorus Res. Bull., 2, 63-68 (1992).

14) K. Itatani, O. Takahashi, A. Kishioka and M. Kinoshita, Gypsum \& Lime, No. 213, 77-85 (1988).

15) T. Keii, "Kyuchaku Kyoritsuzensho, 157", Kyoritsu-shuppan (1980) pp. 22-29, pp. 95-97.

16) N. Okuyama, T. Ogawa and M. Ebihara, Gypsum \& Lime, No. 210, 323-31 (1987).

17) F. Honda, H. Honda and M. Koishi, J. Chromatogr. A, 696, 19-30 (1995).

18) T. Arai and W. Norde, Colloids and Surfaces, 51, 1-15 (1990). 